\title{
Population Structure of two Astyanax Baird \& Girard, 1854 (Teleostei, Characidae) species from Upper Paraguaçu River
}

\author{
Alexandre Clistenes de Alcântara Santos ${ }^{1 *}$ and José Luís Costa Novaes ${ }^{2}$ \\ ${ }^{1}$ Universidade Estadual de Feira de Santana; Laboratório de Ictiologia; Departamento de Ciências Biológicas; Km \\ 03, BR116; Campus Universitário; clister@ig.com.br; 44031-460; Feira de Santana - BA - Brasil. ${ }^{2}$ Universidade \\ Estadual Paulista; Laboratório de Ecologia de Peixes; Instituto de Biociências; Departamento de Morfologia; \\ Distrito de Rubião Júnior, s/no ; 18618-000; novaes@ibb.unesp.br; Botucatu - SP - Brasil
}

\begin{abstract}
The fishes of the family Characidae are among the main species of fresh water fishes in South America. In this work, some aspects of the population structure of two Astyanax species were assessed. The fishes were caught in Santo Antônio and São José rivers, in the Paraguaçu basin, by standardized monthly samplings adapted to the microhabitats. Astyanax sp. b (São José river) presented larger size than Astyanax sp. a (Santo Antônio river). The length-weight relationship showed positive allometric growth for Astyanax $s p . a$, and negative for $\underline{\text { Astyanax }} s p . b$. Both the species showed a long reproductive period, with higher activities in dry period.
\end{abstract}

Key words: Astyanax, Characidae, Chapada Diamantina, Paraguaçu River, population structure

\section{INTRODUCTION}

The Paraguaçu River has one of the largest basins in Northeast Brazil, despite its ichthyologic fauna is still poorly known (Higuchi et al., 1990). This river in Chapada Diamantina, in the central part of Bahia, and its edge waters present a rich endemic ichthyofauna (De Pinna, 1992). It is a perennial river with a number of seasonal intermittent tributaries in the semi-arid region, which discharge its water in Todos os Santos Bay after crossing Pedra do Cavalo dam. Fish collection procedures carried out between 1998 and 1999 in different places along its course have produced a highly diversified fauna with several species still in the process of being described or recently described (Santos 2003).

Among all the tributaries of the upper Paraguaçu River, the Santo Antônio River is the largest, having as its main characteristics perennity and low declivity. Another important tributary is the São José river, which flows form north to south. It presents a number of tributaries in its right bank. The São José has been one of the most affected rivers during the mining of diamonds in the Chapada Diamantina region, thus presenting large deforested areas along its banks and as a result the river is highly silted up.

The fishes locally known as lambaris or piabas are among the main species of fresh water fishes in South America of the Astyanax genus, (Garutti, 1995, 1998). This work deals with population aspects of two abundant species of Astyanax found in Santo Antônio and São José rivers (Fig. 1).

\footnotetext{
${ }^{*}$ Author for correspondence
} 


\section{MATERIAL AND METHODS}

Monthly standard collection procedures were carried out in the areas of about $200 \mathrm{~m}$ in the lower Santo Antônio and São José rivers (12³9'37'’S $41^{\circ} 19^{\prime} 43^{\prime \prime} \mathrm{W}$ and $12^{\circ} 37^{\prime} 19^{\prime \prime} \mathrm{S}-4^{\circ} 22^{\prime} 36^{\prime \prime} \mathrm{W}$ respectively) between August 1998 and July 1999. Three kinds of fishing were used (sieve, gillnet and cast net) in order to collect different segments of local ichthyofauna. Each collection procedure lasted one hour with six-hour intervals over each eighteen-hour period (morning, afternoon and night). Hand net and sieve were used for depths less than $1 \mathrm{~m}$ next to the riverside vegetation, which was made up of bushes and grass rooted to its bank. Cast net was thrown form the bank and each casting reached different depths. The fishes collected were kept in a $10 \%$ formaldehyde solution in plastic bags, which received temporary tags during the collection. Later the specimens were classified by the species, weighed, measured and preserved in alcohol $\left(70^{\circ} \mathrm{GL}\right)$.

Most of the voucher specimens were deposited at the collection of fishes at Museu Nacional in Rio de Janeiro ( $\mathrm{n}^{\mathrm{o}}$ 2514, 2521, 2617, 4060, 4099). Comparative collections at the Museu Nacional in Rio de Janeiro and at the Zoology Museum of Universidade de São Paulo were used.

In order to have an overview of the pluviometric conditions in the region data was obtained from the climatologic station of the National Department of Meteorology in Lençóis for the period between 1993 and 2001 (Fig.2), which showed that the area under study was characterized by a dry period from April through October and a rainy season from the end of November up to March.

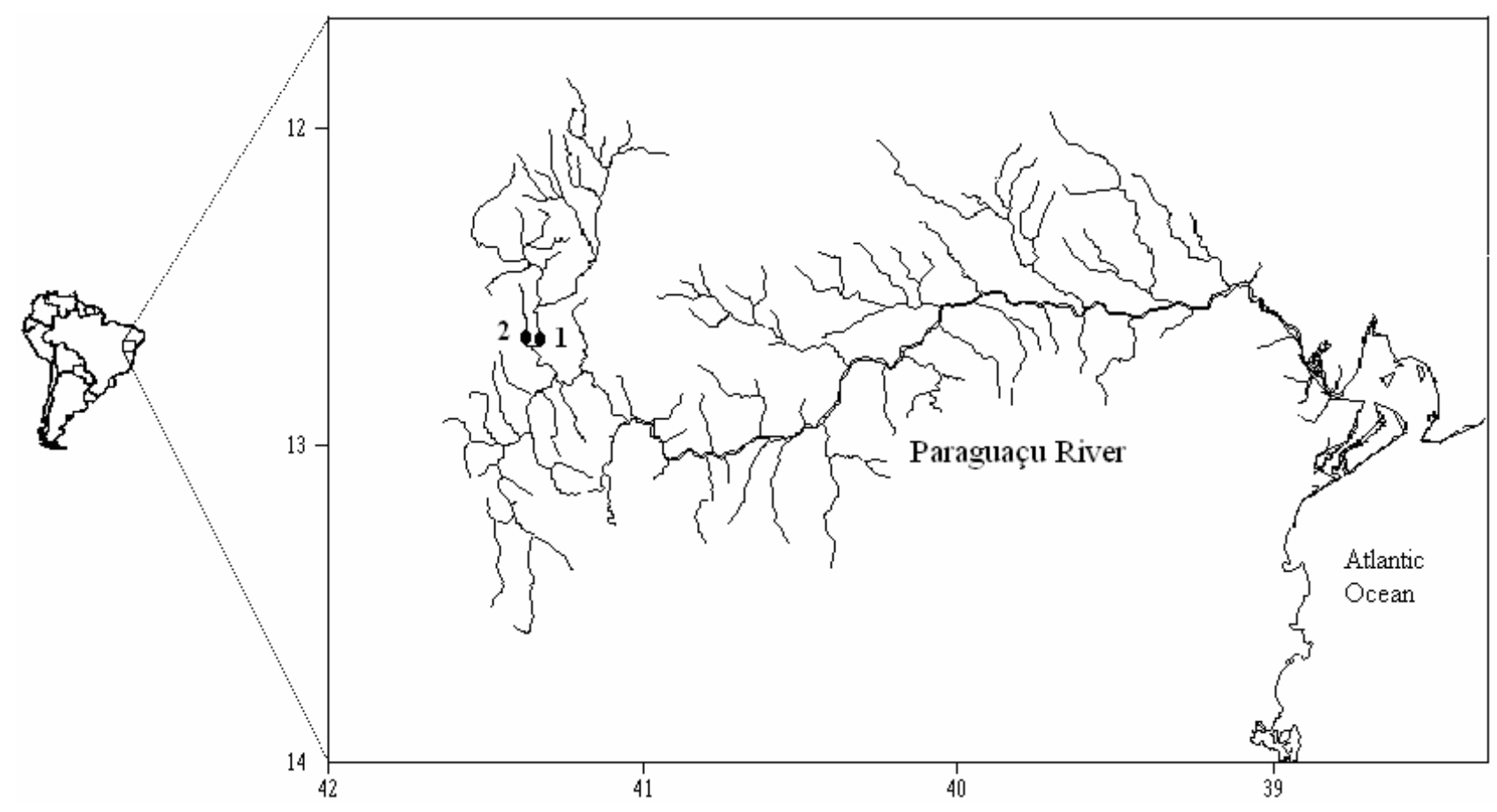

Figure 1 - Location of Paraguaçu, Santo Antônio (1) and São José (2) rivers and the areas under study in each river in Lençóis region, BA. 


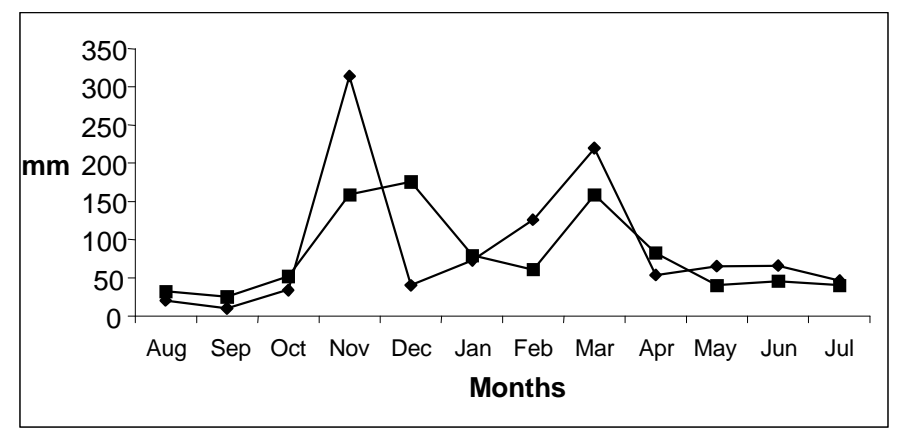

Figure 2 - Average values for monthly rainfall (diamond), during the collection procedures (from August 1998 to July 1999), and the monthly averages (square) between 1993 and 2001, in the Lençois region, BA.

The constancy represented the frequency in which a certain species was found among the samples, allowing to assess its proportion in the community relative to space and time. Dajoz's proposal (2006) was followed in order to understand the results:

$\mathrm{C}=\mathrm{p} 100 / \mathrm{P}$, where: $\mathrm{C}=$ constancy; $\mathrm{p}=$ number of collection procedures in which the species was represented; $\mathrm{P}=$ total number of collection procedures.

C over 50\%: constant species

$\mathrm{C}$ between $25 \%$ and $50 \%$ : accessory species $\mathrm{C}$ inferior to $25 \%$ : accidental or rare species

Data on standard length (SL) and total weight (WT) with an accuracy of a hundredth of a gram was obtained from each specimen under the study. Later, the specimens were dissected and classified according to the sex and stage of reproductive cycle. In order to perform the macroscopic evaluation of the gonads, the following characteristics were considered location in the coelomic cavity, blood irrigation/supply; color and transparency; visibility, size, color and transparency of the ovocytes; weight of the ovaries and testicles.

According to the visual examination the gonads sex and stage of reproductive cycle were assessed. This was based on the macroscopic characteristics defined in a maturation scale made up of eight stages for the females: immature, initial maturation, final maturation, mature, semispawned, spawned, recovering and recovered, and seven stages for the males: immature, maturing, mature, semi-spent, spent, recovering and recovered.
Gonadosomatic Index (GSI) were obtained from the data on total weight and gonad weight for each individual:

GSI $=\mathrm{Pg} / \mathrm{Pt} \times 100$, where: $\mathrm{Pg}=$ gonad weight and $\mathrm{Pt}=$ total weight.

The stages of the reproductive cycle were classified as either reproductive (final maturation, mature and semi-spawned for females and maturing, mature and semi-spent for males), or non-reproductive, comprising the other stages. The percentage of the proportion between reproductive and non-reproductive individuals was calculated per period (dry and rainy).The proportion between the sexes observed was compared to the expected proportion (1: 1, male-female) and the difference was assessed by the Chi-square test $(\chi 2=0.05)$.

The total condition factor was used following the model $\mathrm{K}=\mathrm{SL} / \mathrm{TW}^{\mathrm{b}}$, where: $\mathrm{SL}=$ standard length, $\mathrm{TW}=$ total weight, and $\mathrm{b}=$ parameter for the relationship weight-length. Test $t$ was used on the values for $\mathrm{K}$ which were obtained in order to notice possible changes between dry and wet seasons.

The size for the first maturation of the species of Astyanax in Santo Antônio and São José rivers was established according to Sato and Godinho (1988), who suggested that the smallest specimen in advanced stages of gonad maturation collected be taken as benchmark.

\section{RESULTS AND DISCUSSION}

According to comparisons carried out with the use of material collected in the region and that provided by the technical reserves analyzed in this 
study, together with advice from systematicians who were consulted by the authors, could be establish that both the species were unknown although their preliminary description was now know. The total number of specimens collected during the annual cycle was 284 individuals for Astyanax sp. a (Santo Antônio river) and 1049 individuals for Astyanax sp. b (São José river). In the section of the São José River under study, Astyanax sp. b was the only Astyanax species registered. In the Santo Antônio River, only one other species of Astyanax was identified (Astyanax bimaculatus). Therefore, this information would enable the recognition of the species of Astyanax analyzed in this work.

Both the species were considered constant and relatively very abundant. These results conformed with the pattern of ichtyofauna from the Neotropical region, in which Characiformes prevailed (Lowe-McConnell, 1999), and among these a number of Astyanax species (Buckup, 1999). The great difference between the number of individuals from each species collected was due the difference between the communities under study, which reflected the physical and physiographical differences between the two rivers as observed by Santos (2003). The range of the standard length for the specimens varied from 13.7 to $29.1 \mathrm{~mm}$ for Astyanax sp. a, and from 17.7 to $42.9 \mathrm{~mm}$ for Astyanax sp. b (Fig. 3). Both the species were considered small, but Astyanax sp. b reaches a considerably larger size.

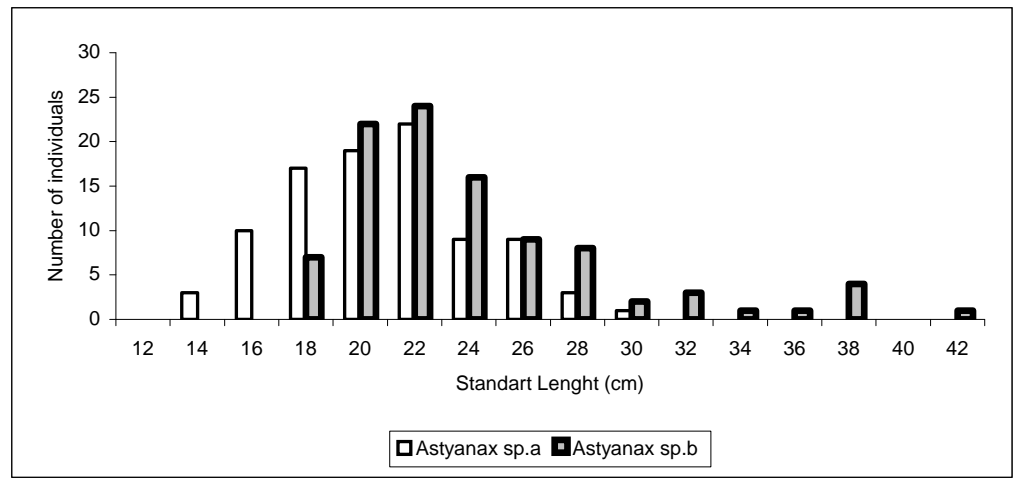

Figure 3 - Distribution of classes for the Astyanax specimens collected in Santo Antônio (Astyanax sp. a) and São José (Astyanax sp. b) rivers between August 1998 and July 1999.

The sex ratio of Astyanax sp. a was $53.9 \%$ for the females and $46.1 \%$ for the males, while Astyanax sp. b presented $62.6 \%$ for the females and $37.4 \%$ for the males, thus having a more significant deviation in the proportion between the malesfemales (Fig. 4). The differences between the sex ratio for both the species were probably related to the particular features of each one. Among some of the factors that might cause predominance of one sex, Vazzoler (1996) mentioned the differentiated growth between the sexes, the formation of schools at spawn with male predominance. The sexual proportion per class of length and/or per phase of gonad development in order to search could be possible causes for this differentiation.
Linear regressions for both the species in the relationship weight-length were as the following: Astyanax sp. a: $\mathrm{y}=7 \mathrm{E}-06 \mathrm{x}^{3.3313}$

Astyanax sp. b: $\mathrm{y}=2 \mathrm{E}-05 \mathrm{x}^{2.9676}$

The linear correlation coefficient was 0.9494 for Astyanax sp. a and 0.8736 for Astyanax sp. b. (Fig. 5). Le Cren (1951) stated that the values for the alometric coefficient varied from 2.0 to 4.0, assuming a value of 3.0 for an "ideal fish", which would keep the same shape during the ontogenetic growth. In this segment the values under or over 3.0 indicated individuals, which became more "elongated" or "rounder" during growth respectively. The results suggested that Astyanax sp. a tended to present more elongated shape when compared to Astyanax sp. b. Thus, the differences found in the alometric coefficient between the two 
species could provide relevant information for the future differentiation of the species.

The average values for the condition factor for both the species were higher in the rainy season for both the sexes. Females presented higher average values of the condition factor (Fig. 6). Assuming that the condition factor reflected the physiologic conditions of the fishes and that it was related to the availability of food, gonad development and size of the individuals, among other aspects, the existence of seasonal and spatial differences in this factor was natural. Higher values for the condition factor during the rainy season suggested that better feeding conditions in this period might have allowed extra reserves and consequently better physiological condition. This could also be related to a larger supply of alochthonous food available in this period, which could be an important argument for the need of preserving the riverside vegetation in the region under study.

The average values of the GSI of the males and females suggested that reproductive activity might be a little higher during the dry season for both the species (Fig. 7). The GSI express the percentage of the gonads in relation to the total weight or the weight of the body for each individual. This could be an efficient indicator of the functional state of ovaries (Wooton, 1990; Vazzoler, 1991; Vazzoler, 1996). For both the Astyanax species, little seasonality between the dry and wet season was observed.

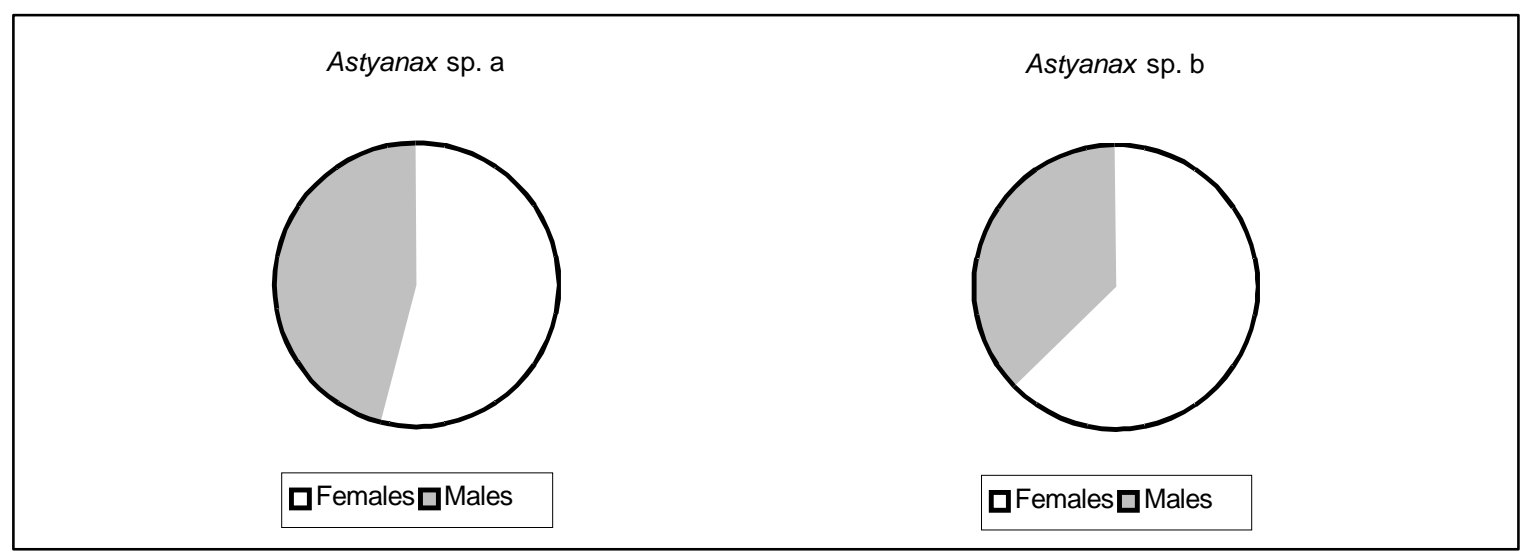

Figure 4 - Proportion of males and females for both species of Astyanax in Santo Antônio and São José rivers.
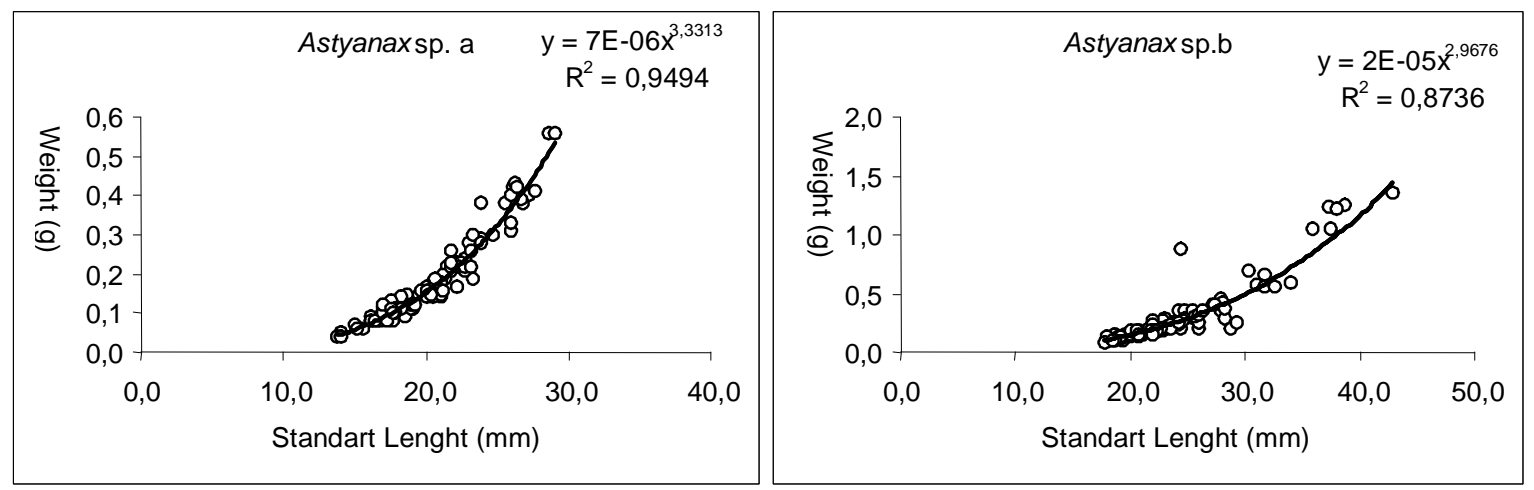

Figure 5 - Weight-length relation for Astyanax sp. a and Astyanax sp. b. 
A high percentage of reproductive individuals were always observed both in the dry and rainy season, which indicated that the Astyanax species presented a wide reproductive period the whole year (Fig. 8). This long reproductive period supported Nikolsk's conclusions (1963) that species from tropical regions tended to present a long reproductive period, which was observed by several other authors (Aranha et al, 1993, Araújo et al, 1999, Araújo and Garutti, 2002 and Mazzoni et al, 2002).

Both the Astyanax species under study presented differences in the populational aspects. Astyanax sp. $b$ reached a larger size and presented higher deviation in the proportion of the male-female, higher average values for the condition factor and a lower value of the alometric coefficient. However, great differences were not observed in the GSI and the proportion between the reproductive and non-reproductive individuals, thus suggesting that both Astyanax sp. a and Astyanax sp. b made similar use of the areas in both the rivers under study, the Santo Antônio and the São José respectively. These results provided important information for the classification and description of the species, which was in its initial phase. Vazzoler and Menezes (1992) mentioned the need to implement studies on the reproductive biology of Characiformes, which comprised species, which supported the main fishing industry in the continental waters in South America. Since then, a few studies have been carried out on the biology and ecology of species in this group. However this is still lack of the specific studies on the different species of Astyanax.

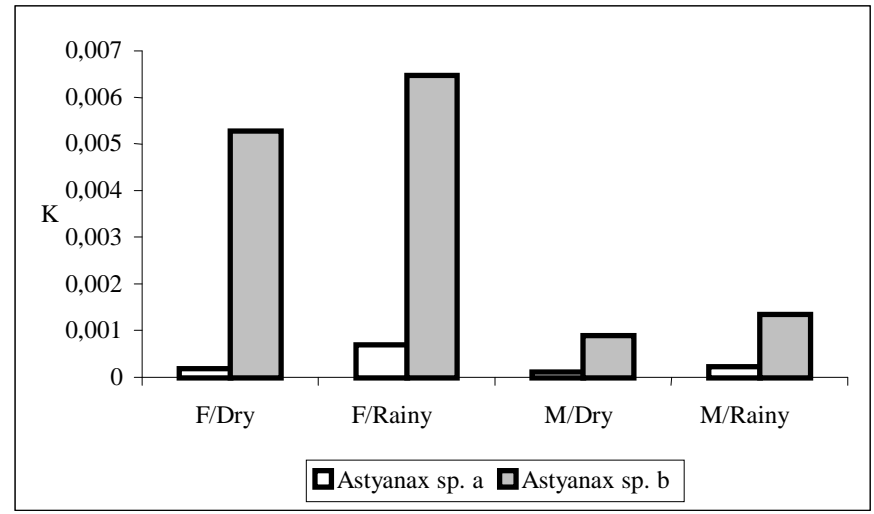

Figure 6 - Seasonal variation of the condition factor for Astyanax sp. a and Astyanax sp. b during dry and wet months (F: females; M: males).
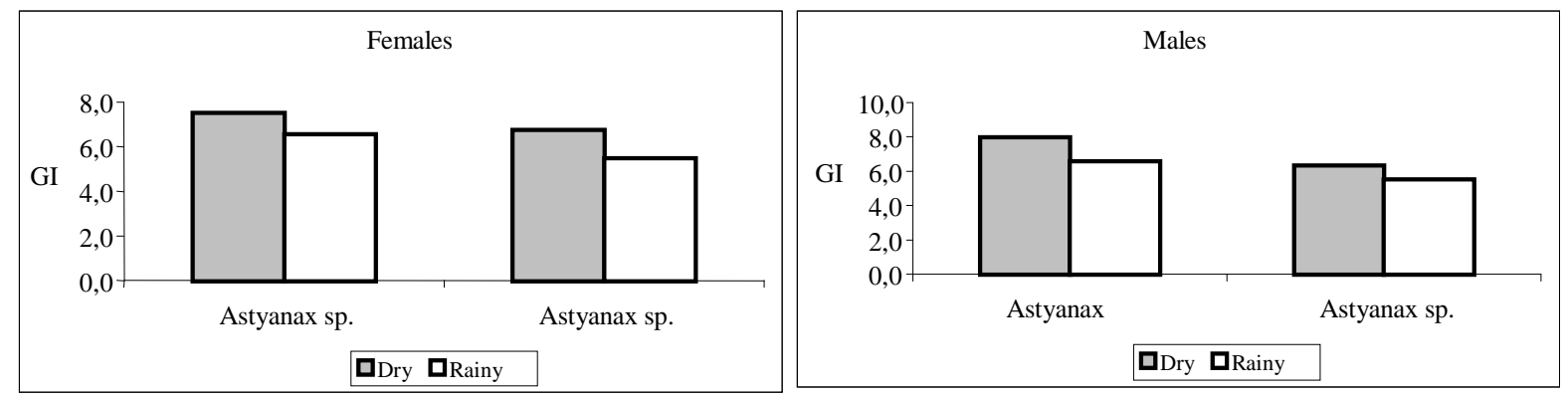

Figure 7 - Gonadossomatic index of males and females for both Astyanax species in dry and wet periods. 

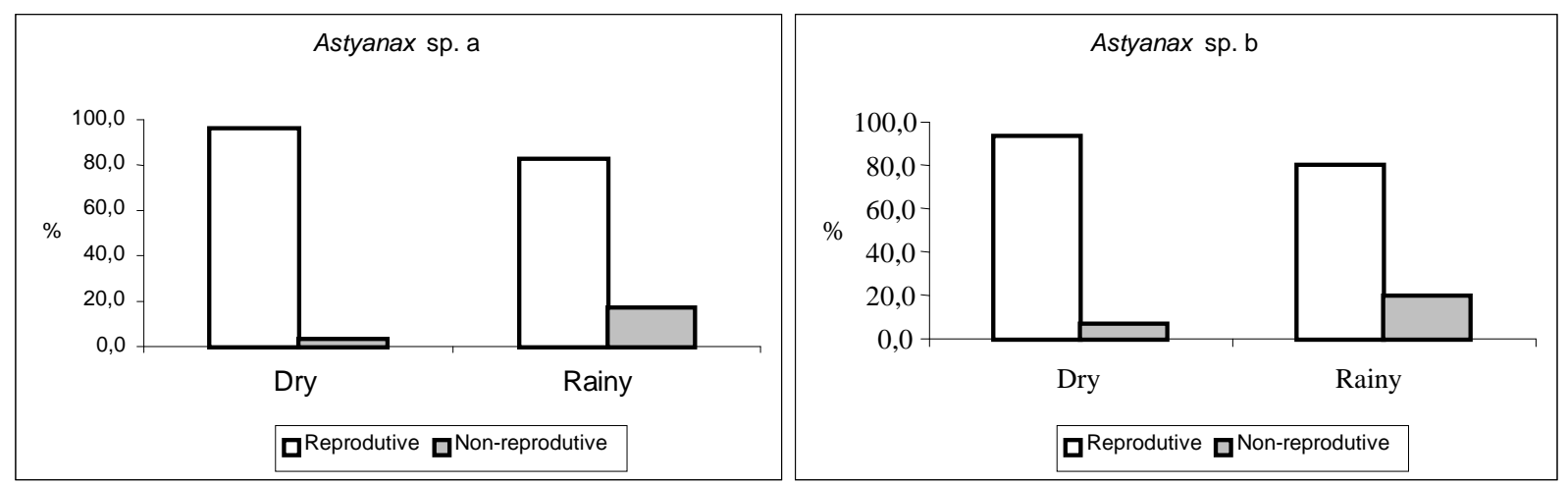

Figure 8 - Relative frequency of reproductive and non-reproductive females of Astyanax sp. a and Astyanax sp. b during dry and wet season

\section{ACKNOWLEDGEMENTS}

We thank to the Capes for granting the scholarship during part of this study, to Dr. Érica P. Caramaschi at UFRJ for allowing to use the Laboratório de Ecologia de Peixes (Laboratory of Ecology of Fishes) during this work, to Projeto Nordeste de Pesquisa/CNPq and to UEFS for the support on the collection procedures, to Marconi P. Sena (UEFS) for his help in this process as well as in the triage of the material, to Claudia Cunha for help in the English, to Claudia Angélica da Silva Brandão (in memoriam) for the support and help during the initial steps of this study.

\section{RESUMO}

Os peixes da família Characidae estão entre os principais representantes de peixes de água doce da região Neotropical. Este trabalho apresenta alguns aspectos da estrutura populacional de duas espécies de Astyanax coletadas a partir de amostragens mensais padronizadas e adaptadas a diferentes microhabitats, em trechos dos rios Santo Antônio e São José, tributários do alto curso do rio Paraguaçu. Astyanax sp. b, coletada no rio São José apresentou maior tamanho que Astyanax sp. a, coletada no rio Santo Antônio. A relação pesocomprimento indicou um crescimento alométrico positivo para Astyanax sp. a e negativo para Astyanax sp. b. Ambas as espécies apresentaram um longo período reprodutivo, com maior atividade reprodutiva no período seco.

\section{REFERENCES}

Aranha, J. M. R., Caramaschi, E. P. and Caranaschi, U. (1993). Ocupação espacial, alimentação e época reprodutiva de duas espécies de Corydoras Lacépède (Siluroidei, Callichthydae) coexistentes no rio Alambari (Botucatu, São Paulo). Revta. Bras. Zool., 10:(3), 453-466.

Araujo, R. B. and Garuti, V. (2002). Biologia reprodutiva de Aspidoras Fuscoguttatus (Siluriformes, Callichthyidae) em riacho de cabeceira da bacia do alto rio Paraná. Iheringia, Ser. Zool., 92:(4), 89-98.

Araújo, F. G., Duarte, S., Goldberg, R. S. and Fichberg, I. (1999). Indicadores reprodutivos de Parauchenipterus striatulus (Steindachner) (Pisces, Auchenipteridae) na Represa de Ribeirão das Lajes, Rio de Janeiro, Brasil. Revta. Bras. Zool., 16:(4), 1071-1079.

Buckup, P. A. (1999). Sistemática e biogeografia de peixes de riachos. In: Ecologia de peixes de riachos. ed. E. P Caramaschi,., R Mazzoni,. and P.R PeresNeto,. Série Oecologia Brasiliensis,vol.VI., Computer and Publish Editoração, Rio de Janeiro, pp. 91-138.

Dajoz, R. (2006). Princípios de ecologia . Ed. Artmed Sétima Edição, Porto Alegre. 519 pp.

De Pinna, M. C. C. (1992). A new subfamily of Trichomycteridae (Teleostei, Siluriformes), lower loricarioid relationships and a discussion on the impact of additional taxa for phylogenetic analysis. Zoological Journal of the Linnean Society, 106, 175229.

Garutti, V., (1995). Revisão taxonômica dos Astyanax (Pisces, Characidae), com mancha umeral ovalada e mancha no pedúnculo caudal, estendendo-se à extremidade dos raios caudais medianos, das bacias do Paraná, São Francisco e Amazônica. Tese de Livre Docência, IBILCE-UNESP, São José do Rio Preto, SP, viii + 286 pp. 
Garutti, V., (1998). Descrição de uma espécie nova de Astyanax (Teleostei, Characidae) da bacia do Tocantins, Brasil. Iheringia, Ser. Zool., Porto Alegre, 85, 115-122.

Higuchi, H., Britski, H. A. and Garavello, J. C. (1990). Kalyptodoras bahiensis, a new genus and species of thorny catfish from norteastern Brazil (Siluriformes: Doradidae). Ichthyol. Explor. Freshwaters, 1: (3), 219-225.

Le Cren, E. D. (1951). The length-weight relationship and seasonal cycle in gonad weight and condition in the perch (Perca fluviatilis). J. Anim. Ecol., 20, 201219.

Lowe-McConnell, R. H. (1999). Estudos ecológicos em comunidades de peixes tropicais. Editora da Universidade de São Paulo, São Paulo, 534 pp.

Mazzoni, R., Caramaschi, E. P. and Fenerich-Verani, N. (2002). Reproductive biology of a Characidiinae (Osteichthyes, Characidae) from the Ubatiba river, Maricá-RJ. Brasilian Journal of Biology, 62: (3), 487-494.

Nikolsky, G. V., 1963, The ecology of fishes. Academic Press, London, 352p.
Santos, A. C. A. (2003). Caracterização da ictiofauna do alto rio Paraguaçu, com ênfase nos rios Santo Antônio e São José (Chapada Diamantina, Bahia).PhD Thesis. UFRJ/ Museu Nacional, Rio de Janeiro. 251pp.

Sato, Y. and Godinho, H. P. (1988). A questão do tamanho de primeira maturação dos peixes de Três Marias, MG. In: Associação Mineira de Aquicultura. Coletânea de resumos dos Encontros da Associação Mineira de Aquicultura, 1982-1987, Brasília.

Vazzoler, A. E. A. M. (1991). Manual de métodos para estudos biológicos sobre populações de peixes. Crescimento e Reprodução. CNPq. Programa Nacional de Zoologia. Brasília, 108 pp.

Vazzoler, A. E. A. M. (1996). Biologia da reprodução de peixes teleósteos: teoria e prática. Maringá, EDUEM; São Paulo, 156 pp.

Vazzoler, A. E. A. M and Menezes, N. A. (1992). Síntese de conhecimentos sobre o comportamento reprodutivo dos Characiformes da América do Sul (Teleostei, Ostariophysi). Revta. Brasil. Biol., 52:(4), 627-640.

Wootton, R. J. (1990). Ecology of teleost fishes. London-New York, Chapman and Hall, 404 pp. 